\title{
CORRELATION OF SCHOOL LITERATION WITH THE RESULTS OF LEARNING ON MATHEMATIC IN THE SITUSARI O1 ELEMENTARY SCHOOL
}

\author{
Nurlinda Safitri ${ }^{1)}$, Lia Octaviani ${ }^{1)}$ \\ ${ }^{1)}$ Universitas Pakuan, Bogor, Indonesia \\ Corresponding Author: nurlinda@unpak.ac.id
}

\begin{abstract}
This research is about the correlation study with the school literacy as independent variable and result of learning mathematics as dependent variable. The main purposes of the research is for find out relation between school literacy with result of learning mathematics. The research implemented at March 2018 and use survey research with correlational approachment. The subject on the research are students four grade in the Situsari 01 Elementary School with 101 students. Sampling from formula calculation is 50 student using Taro Yamane formula with 10\%. The technique of data analysis are regretion technique analysis and simple correlation. Regretion technique analysis and simple correlation produce a relation model otherwise in type equation $\hat{\mathrm{Y}}=-22,12+0,86 \mathrm{x}$, with Fhitung is 48 bigger than Ftabel with the real level 0,05 with 4,04 , and be based on contribution the outcomes of research is $94 \%$, so can summed up that there is a positive and significant relation between school literacy with result of learning mathematics.
\end{abstract}

Keywords: School Literacy, Learning outcomes, Mathematics

\section{INTRODUCTION}

Education is the most important factor and a top priority that requires serious attention from all parties, because education is a determinant of the nation's progress in the future[1]. National goals and ideals, for the intellectual life of the nation is contained in the 1945 Constitution. The government together with the community continues to seek the development of education for the realization of an independent, superior and ready nation to face the globalization world [2]. Parenting is a habit that is usually done by fathers and mothers that are applied to children in their development [3]. Based on this, it can be understood that education is very important for human life. The purpose of education is to prepare students to be able to play an important role in their lives in the future. Likewise with the implementation of education that cannot be separated from a goal to be achieved. This is strongly supported by a 2013 curriculum program that has been planned by the Ministry of Education and Culture. This 2013 curriculum-based learning will run well if the school can hold school literacy or the School Literacy Movement (GLS).

School literacy is an effort that can be carried out thoroughly and continuously to make the school an organization of learning that can be carried out by all circles in the school including teachers and students with various activities including reading, seeing, listening, writing, counting and speaking.

Learning outcomes are abilities acquired by students after going through learning activities.
Through the learning process, students are expected to achieve learning goals in the form of values. Learning objectives can show that students have done the act of learning at school and outside the school environment, learning outcomes in general include aspects of knowledge skills and new attitudes expected to be achieved by students. Mathematics is an ability to think and solve problems in everyday life and as a basic science that needs to be mastered well by students.

Based on the description above, it is expected that students can improve learning outcomes on mathematics subjects, but the fact is that learning outcomes are still low. From the results of observations of class IV students totaling 101 students, it was seen that student learning outcomes in mathematics subjects still seemed low. At the Situsari 01 Elementary School, there are 7.8 Minimum Completion Criteria (KKM) on mathematics subjects. As for those who are still under KKM class IV A as many as 19 people or $52 \%$, class IV B as many as 14 people or $40 \%$, and class IV C as many as 12 people or $40 \%$. The school has implemented 15 minutes of reading before starting learning in class, but there are some students who still have not implemented reading activities before learning begins.

Based on the data above, it is necessary to research how much school literacy is on student learning outcomes and to see whether or not there is a relationship between the two. For that the author conducted a study entitled "Relationship between School Literacy and Learning Outcomes in 
Mathematics Subjects in the Situsari 01 Elementary School.

Based on the background of the problem above, the research problem can be formulated as follows: Is there a relationship between school literacy and student learning outcomes on mathematics subjects in the Situsari 01 Elementary School.

The nature of learning outcomes, human beings and learning are two words that are difficult to separate, because without learning humans cannot know themselves, others and their environment. Taufik [4] explain that learning is defined as a change in behavior that is relatively settled which occurs because of experience. Through this experience students can find out the extent to which behavior changes occur to him. In line with Rusman [5] which suggests that learning outcomes are a complex process and behavioral changes occur when the learning process is observed in changes in student behavior after assessment. The assessment was carried out to determine the extent to which students achieved success in the learning process.

Every learning process is always characterized by the characteristics that are in it, by knowing the characteristics of learning outcomes then learning outcomes will be obtained. Characteristics are references or guidelines given in providing assessment of learning outcomes to students. These characteristics according to Widoyoko [6] that the assessment of student learning outcomes in schools based on the 2013 curriculum have five characteristics of learning outcomes, namely complete learning, authentic, continuous, based on reference criteria, and using varied assessment techniques. Learning outcomes assessment is closely related to the goals to be achieved in a learning process. In line with the opinion of Idrus [7] that the assessment of learning outcomes can basically reveal all aspects of the domain in a learning process, namely such as cognitive, affective and psychomotor aspects.

Susanto [8] argues that mathematics is one of the fields of study that exists in all education majors, from elementary school to college level, even mathematics is taught informally in childhood. Mathematics for elementary students is very useful for the benefit of life in the environment and to develop the mindset of students.

Meanwhile, according to Karso [9] who suggested that mathematics at elementary school is one of the studies that is always interesting to put forward because of the special differences in characteristics between the nature of the child and the nature of human beings. Mathematics needs to be taught in schools so students can meet needs that can expand their thinking knowledge. Therefore mathematics for elementary school students is very useful and important especially for the benefit of life in the environment, so students can develop their mindset and can learn other sciences.
Integral material, integers are sets of numbers consisting of negative integers, zeros and positive integers. Integers are divided into two types, namely negative integers and positive integers.

Based on several theories above, it can be synthesized that mathematics learning outcomes are the achievement of learning outcomes from learning activities carried out by students and carried out continuously based on the abilities possessed by students both from spiritual attitudes, social attitudes, and skills, based on indicators of assessment of integer learning outcomes, sort integers, add integers, subtract integers, and calculate integer integers.

The nature of school literacy, school literacy is needed in the school environment especially for students and other parties involved in the school environment. Traditionally, literacy is seen as the ability to read and write. Literacy in English literacy comes from Latin littera (letters) whose understanding involves mastery of writing systems and accompanying conventions. Abidin [10] argues that literacy is defined as the ability to use rich and varied forms of language and images to read, write, listen, speak, see, present and think critically about ideas or ideas.

The gate of elementary school education is an important initial foundation for growing children's love for literacy or reading activities. School literacy confirms that schools must strengthen movements to foster students' abilities in the learning process. The central government has issued a regulation on the minister of education and culture No. 23 of 2015 concerning the growth of character. One of the regulations is about the culture of reading which begins with reading 15 minutes before the lesson starts in all schools. This is as stated by Anggraeni [11] that school literacy is the first step to grow children's love to read 15 minutes before learning begins, the activity is expected to grow reading interest in children increases.

The purpose of school literacy according to Heryawan [12] is to provide general information and descriptions of the School Literacy Movement and as a guide for schools and literacy activists to be able to carry out these activities well. So from that the purpose of school literacy is very necessary to find out what the activities will be carried out. The implementation of school literacy according to Widya [13] suggests that the main target of school literacy in the education environment is at school at the elementary school level. The implementation of this school literacy program can be seen from the discipline of students, the willingness of students to develop reading interest in students in schools and outside the school environment which is carried out in three stages, namely habituation, development stage and learning stage.

Based on the theory study above, it can be synthesized that school literacy is habituation in understanding a skill in reading, writing, speaking and counting on an ongoing basis to make civilization in 
school literacy by achieving indicators of habituation, development and learning so students become lifelong learners.

\section{RESEARCH METHODS}

The study was conducted in the fourth grade of the Situsari 01 Elementary School Even Semester 2017/2018 Academic Year conducted in March 2018. The population in this study were all fourth grade students of the Situsasri 01 Primary School Even Semester Academic Year 2017/2018 which amounted to 101 students consisting of three classes, namely classes IV A, IV B and IV C. The samples used in the study were simple random sampling using the Taro Yamane formula. The number of research samples is 50 students, each for class IV A there are 17 students, class IV B there are 17 students, and class IV C there are 16 students.

The technique of collecting data uses two types of data, the results of mathematics learning using test instruments and school literacy using questionnaires in the form of statements with 5 alternative answers.

\section{RESULTS AND DISCUSSION}

The results of the data analysis hypothesis testing data that there is a positive relationship between a positive and significant relationship between school literacy and learning outcomes on mathematics subjects. This shows that the research hypothesis is accepted, meaning that school literacy contributes to learning outcomes.

The functional relationship between a positive and significant relationship between school literacy and learning outcomes in mathematics subjects by statistical analysis is shown by the results of significance and regression test $\hat{Y}=-22.12+0.86 \mathrm{X}$. This means that every increase in one unit of school literacy variables causes an increase in mathematics learning outcomes of 0.86 units.

The strength of the relationship between a positive and significant relationship between school literacy and learning outcomes in mathematics subjects is indicated by a correlation coefficient of 0.975 . The price coefficient shows that there is a very strong relationship between the positive and significant relationship between school literacy and learning outcomes in mathematics subject to determination $\left(\mathrm{r}^{2}\right)$ of 0.94 . This means that raising and decreasing the activity of social studies learning is influenced by the level of interpersonal communication by $94 \%$, while the remaining $6 \%$ is influenced by other factors.

Based on the analysis of hypothesis testing that has been done, obtained the results of the correlation sub-variable reading ability $\left(\mathrm{X}_{1}\right)$ with the variable student learning outcomes $(\mathrm{Y})$ of $0.559>0.297\left(\mathrm{r}_{\text {count }}>\right.$ $\mathrm{r}_{\text {table }}$ ), so the hypothesis is accepted. The result of the writing ability sub-variable correlation $\left(\mathrm{X}_{2}\right)$ with the student learning outcome variable $(\mathrm{Y})$ is $0.567>0.297$ $\left(r_{\text {count }}>r_{\text {table }}\right.$ ), so the hypothesis is accepted. It can be seen that there is a positive relationship to student learning achievement with correlation coefficient (r_xy) of 0.436 so that there is a relationship between literacy ability and learning outcomes.

\section{CONCLUSION}

Based on the results of data processing, this can be shown through the calculation of the correlation coefficient $(r)=0.975$ which indicates that there is a very strong relationship between school literacy and learning outcomes. The magnitude of the school literacy relationship with the mathematics learning outcomes through the regression equation $\hat{Y}=-22.12+$ $0.86 \mathrm{x}$, meaning that if the school literacy activities amount to one unit, then the mathematics learning outcomes will increase. Furthermore, the coefficient of determination $\left(r^{2}\right)$ is 0.94 or $94 \%$. This means that the increase or decrease in mathematics learning outcomes is influenced by school literacy $94 \%$, while $6 \%$ of mathematics learning outcomes are influenced by other factors.

\section{REFERENCES}

[1] Y. Suchyadi and Nurjanah, "Relationship between Principal Supervision in Increasing the Job Satisfaction of Private Junior High School Teachers in East Bogor District," J. Humanit. Soc. Stud., vol. 02, no. 01, pp. 26-29, 2018.

[2] Y. Suchyadi, "Relationship between Work Motivation and Organizational Culture in Enhancing Professional Attitudes of Pakuan University Lecturers," vol. 01, no. 01, 2017.

[3] S. Setiarani and Y. Suchyadi, "Pola Asuh Orang Tua Terhadap Anak Tuna Netra Berprestasi," $J$. Pendidik. Pengajaran Guru Sekol. Dasar, vol. 01, no. 01, pp. 15-18, 2018.

[4] Taufik Agus Dkk. 2012. Pendidikan Anak di $S D$. Tanggerang: Universitas Terbuka.

[5] Rusman. 2015. Pembelajaran Tematik Terpadu. Jakarta: Raja Grafindi Persada.

[6] Widoyoko, S. Eko P. 2014. Hasil Pembelajaran Di Sekolah. Yogyakarta Pustaka Pelajar.

[7] Idrus, Ali. Manajemen Pendidikan Global. Jakarta.

[8] Susanto, Ahmad. 2013. Teori Belajar dan Pembelajaran. Jakarta: Prenadamedia Group.

[9] Karso, dkk. 2009. Pendidikan Matematika 1. Jakarta: Universitas Terbuka.

[10] Abidin Yunus, Dkk. 2017. Pembelajaran Literasi. Bandung: Perpustakaan Nasional. 
[11] Anggraeni Yetti D. N. 2016. Membangun Budaya Literasi Di Satuan Pendidikan. Artikel Simposium GTK.

[12] Heryawan, Netty Prasetiani. 2016. Buku Panduan Gerakan Literasi Sekolah. Bandung: Dinas Pendidikan.

[13] Widya, Hanata. 2017. Pengaruh Program Gerakan Literasi Sekolah Terhadap Minat Baca Siswa di SD Terpadu Muhammadiyah An-Najah Jatinom Klaten. E-Jurnal FIP-UNY. 